\title{
Distribution, abundance and morphometry of Atlantoraja cyclophora (Regan, 1903) (Elasmobranchii: Rajidae) in southern Brazil, Southwestern Atlantic
}

\author{
María Cristina Oddone* and Carolus Maria Vooren**
}

\begin{abstract}
A total of 459 individuals of Atlantoraja cyclophora were captured along the Rio Grande do Sul coast between latitudes $30^{\circ} 40^{\prime} \mathrm{S}$ and $34^{\circ} 30^{\prime} \mathrm{S}$. Two surveys were performed, in the winter 2001 and in the summer/autumn 2002, using bottom-trawl between the depths of 100 and $600 \mathrm{~m}$. This species occurred between 100 and $300 \mathrm{~m}$ deep, without significant differences in the frequency of occurrence and abundance (CPUE; kg/hour) between latitudes, depth and seasons. The sex ratio was not significantly different from $1: 1 \mathrm{in}$ all depths. In the study area, temperature ranged between $10.0^{\circ} \mathrm{C}$ and $17.6{ }^{\circ} \mathrm{C}$ and salinity between 35.2 e $36.0 \mathrm{ppm}$. There was no correlation between CPUE and depth, temperature and salinity. Mean total length of females $(53.2 \mathrm{~cm})$ was significantly larger than males $(50.9 \mathrm{~cm})$. No differences were detected in mean total length between seasons, but mean total length was significantly larger in depths of $100 \mathrm{~m}$ and $200 \mathrm{~m}$. The distribution of the frequencies of total length was asymmetric, indicating rareness or lack of juveniles in the samples.
\end{abstract}

Foram capturados 459 exemplares de Atlantoraja cyclophora na costa do Rio Grande do Sul entre as latitudes $30^{\circ} 40^{\prime} \mathrm{S}$ e $34^{\circ} 30^{\prime}$ S, em dois cruzeiros realizados respectivamente no inverno de 2001 e no verão/outono de 2002 , com rede de arrasto de fundo, operada entre 100 e $600 \mathrm{~m}$ de profundidade. A espécie ocorreu nas profundidades de 100 a $300 \mathrm{~m}$, não havendo diferenças significativas na frequiência de ocorrência nem na abundância (CPUE; kg/hora) entre latitudes, estratos de profundidade em ambas estações do ano. A proporção sexual não foi significativamente diferente de 1:1 em todas as profundidades. $\mathrm{Na}$ área estudada a temperatura variou entre $10,0^{\circ} \mathrm{C}$ e $17,6^{\circ} \mathrm{C}$ e a salinidade entre 35,2 e $36,0 \mathrm{ppm}$. Não houve correlação entre CPUE e profundidade, temperatura e salinidade. O comprimento total médio das fêmeas $(53,2 \mathrm{~cm})$ foi significantemente maior que o dos machos $(50,9 \mathrm{~cm})$. Não houve diferença no comprimento total médio entre estações do ano, mas sim entre profundidades, sendo significantemente maiores nos estratos de 100 a $200 \mathrm{~m}$. As distribuições de freqüências de comprimento total foram assimétricas, indicando ausência ou escassez de indivíduos juvenis.

Key words: abundance, distribution, occurrence, sex ratio, morphometry.

\section{Introduction}

The family Rajidae Bonaparte, 1831 is the most important of the order Rajiformes, comprising 228 species (Menni, 1972; McEachran \& Dunn, 1998). In Brazilian coastal waters, five species were listed by Figueiredo (1977) for the genus Raja Linnaeus 1768: Raja agassizi (Müller \& Henle, 1841); $R$. castelnaui Ribeiro, 1907; R. platana Günther, 1880; $R$. sadowskii Krefft \& Stehmann, 1974 and $R$. cyclophora Regan, 1903. Atlantoraja was established by Menni (1972) as a new subgenus of Raja, with two species: Raja (Atlantoraja) cyclophora and $R$. (A.) castelnaui, and later considered a valid genus and separated from Raja by McEachran \& Dunn (1998). This action turns Atlantoraja cyclophora (Regan 1903) the valid name for the studied species.

A diagnostic external feature of A. cyclophora, popularly known in Brazil as "raia-santa", is the presence of one ocellus formed by two concentric black circles in the dorsal surface of each pectoral fin (Figueiredo, 1977). There is an intraspecific variation in the thickness of the internal circle and this can be complete or not (Barbosa \& Gomes, 1998). A ocellus is also present in several species of Raja of the Occidental Atlantic

*Universidade Estadual Paulista, Instituto de Biociências, Departamento de Ecologia, Campus Rio Claro, Av. 24-A 1515 - CP 199, 13506-900 Rio Claro, São Paulo, Brazil. e-mail: mcoddone@rc.unesp.br

** Departamento de Oceanografia, Laboratório de Elasmobrânquios e Aves Marinhas, Fundação Universidade Federal do Rio Grande, Caixa Postal 474, 96201-900 Rio Grande, RS, Brazil. 
(Raja texana, $R$. cervigoni, and R. ackleyi; Uyeno et al., 1983), but A. cyclophora differs in possessing a smooth dorsal region of the disc, with one medial series of spines in the tail only, in specimens of all sizes (Figueiredo, 1977).

The family Rajidae has a word wide distribution, inhabiting the sublittoral to abyssal zone, being predominant in the continental shelf and continental slope (Stehmann, 1970). Most species have a restricted geographical distribution and a few ones present large distributions (Walker \& Ellis, 1998). Atlantoraja cyclophora is endemic to the South Atlantic Occidental, occurring in the Brazilian and Bonaerense districts, from Cabo Frio, Rio de Janeiro, Brazil $\left(22^{\circ} \mathrm{S}\right)$ to Golfo de San Jorge, Argentina $\left(47^{\circ} \mathrm{S}\right)$ (Menni \& Stehmann, 2000). Bigelow \& Schroeder (1953) classified this species as belonging to the temperate warm climate of Eastern South America coast.

In Argentina, this species is more frequent in coastal waters, but it is common in the Uruguayan shelf through the $200 \mathrm{~m}$ isobath (Cousseau \& Perrotta, 2000). Uyeno et al. (1983) have also registered this species in French Guiana and Suriname. In such a case, A. cyclophora is the species that reaches the largest Northern distribution among the species inhabiting the Southern Atlantic (Menni \& Stehmann, 2000). Atlantoraja cyclophora is frequent in Southern Brazil, occurring all along the year without seasonal fluctuations in abundance and completing its life cycle in the area (Vooren, 1997). In Brazil, the species inhabits the sea bottom near the coast (Figueiredo, 1977) up to $300 \mathrm{~m}$ depth (Vooren, 1997).

In this paper we intended to establish the bathymetric and latitudinal distribution of A. cyclophora as well as to analyze the frequency of occurrence according to depth and season. We also determined correlations between abundance (indexed by the Catch per Unit Effort - CPUE), temperature, salinity and depth. Finally, we described the length frequency distribution and we presented some morphometric characteristics of the species.

\section{Material and Methods}

Atlantoraja cyclophora samples were obtained through six surveys using bottom-trawl in the external borders of the continental shelf and upper continental slope, aboard of R/V "Atlântico Sul". The surveys were performed in the winter 2001 and in the summer/autumn 2002. Each expedition included three surveys. Winter surveys occurred from 8 to 11 August, 14 to 24 August and 31 August to 12 September 2001. Summer/autumn surveys occurred from 23 to 24 March, 2 to 11 April and 16 to 26 April 2002. These will be referred as winter and summer along the text, even the 2002 samples include the beginning of autumn. Samples of the captured individuals were deposited in the Laboratório de Elasmobrânquios e Aves Marinhas, Departamento de Oceanografia, Fundação Universidade de Rio Grande (FURG).

The studied area was located between the latitudes of

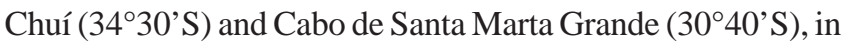
depths of 100 to $600 \mathrm{~m}$. The bottom-trawl net used to collect fish presented 439 meshes long with mesh sizes of $160 \mathrm{~mm}$ near the opening and mesh sizes of $70 \mathrm{~mm}$ near the bag (end of the net). Conductivity-Temperature-Depth (CTD) casts were conducted in each station.

A stratified sampling design was employed, with track lines perpendicular to the coast and approximately $100 \mathrm{~km}$ width, divided in seven depth sections of 100-149, 150-199, 200-249, 250-299, 300-399, 400-499 and 500-699 m, with one sampling station in each section. The sampling station position was determined according to the appropriateness of the bottom to bottom-trawl, with the use of the ecosounder track line. Tow duration was 30 minutes. CTD was taken at the final point of the tow.

It was measured the total length ( $\mathrm{TL}, \mathrm{mm}$ ), from snout tip to posterior tip of caudal fin, the disk width (DW, $\mathrm{mm}$ ), between the lateral tips of the pectoral fins, total weight (TW) and eviscerated weight $(\mathrm{EW})(\mathrm{g})$ of each individual of $A$. cyclophora. Eviscerated weight corresponds to body weight without digestive tract, liver, gonads and without oviduct in females.

Abundance was indexed by the Catch per Unit Effort (CPUE) by hour of tow. The relative frequency of occurrence (FO) was determined through the number of tows where the species occurred divided by the total number of tows (\%). Statistical tests included ANOVA unifactorial and bifactorial (Zar, 1984), Student " $t$ " test (Sokal \& Rohlf, 1987), chi-square test $\left(\chi^{2}\right)($ Chase, 1976) and "F" test (Souza, 1998). A bifactorial ANOVA was employed to analyze the differences among the four depth strata from 100 to 299 m relative to CPUE, sex and season. The Chi-square test $\left(\chi^{2}\right)$ was used in the comparison of the means of the CPUE of each sex, frequency of occurrence and sex ratio in the four depth strata between seasons. Means of temperature and salinity regarding depth and seasons were evaluated separately through unifactorial ANOVA. A "t" test was used to verify differences of temperature and salinity between the areas of occurrence and non-occurrence of the species. Metric and logarithmic scales were used to test correlation between CPUE and salinity, temperature and depth. In the analysis of TL variation regarding depth (100-149; 150199; 200-249; 250-300 m), season (winter, summer) and sex, an trifactorial ANOVA was applied. A residual analysis was performed to validate the models. The " $F$ " test was used to verify differences between sexes in the relations between DW-TL, TW-TL and EW-TL. The symmetry of the distributions of frequencies of total lengths was calculated according to Zar (1984).

\section{Results}

Bathymetric distribution and frequency of occurrence. A total of 459 individuals of Atlantoraja cyclophora, including 245 females and 214 males was captured. The species occurred in 24 of the 58 winters tows and in 29 of the 55 summer tows, with a frequency of occurrence of $41 \%$ and $53 \%$, respectively, in all latitudes of the studied area (Fig. 1a-d), without differences in the spatial distribution between the two studied seasons. The ANOVA did not detect significant differences among the four depth strata from 100 to $299 \mathrm{~m}$ relative to 
CPUE, sex and season $\left(\mathrm{F}_{(3,119)}=0.23 ; P=0.88\right)$ (Table 1$)$. According to $\chi^{2}$ test, there were no significant differences between CPUE of both sexes in each depth stratum (winter: $\chi^{2}$, $=2.19 ; P=0.14$; summer: $\chi_{1}^{2}=1.48 ; P=0.22$ ).

The bathymetric distribution of the species ranged from 100 to $299 \mathrm{~m}$. In summer, the frequency of occurrence in the four depth strata together (100-149; 150-199; 200-249 and 250$299 \mathrm{~m}$ ) was $71 \%$, and $62 \%$ in the winter, being not significant $\left(\chi_{1}^{2}=0.03 ; P=0.86\right)$. The total CPUE between 100 and $299 \mathrm{~m}$ was $46.0 \mathrm{~kg} /$ hour in the summer and $42.3 \mathrm{~kg} /$ hour in the winter, also not significantly different $\left(\chi_{1}^{2}=0.04 ; P=0.77\right)$. Sex ratio was $1.17: 1$ both in the summer and winter, not significantly different from 1:1 (winter: $\chi^{2}=0.66 ; P=0.42$; summer: $\chi_{1}^{2}=$ $1.50 ; P=0.22$ ) (Table 1$)$.
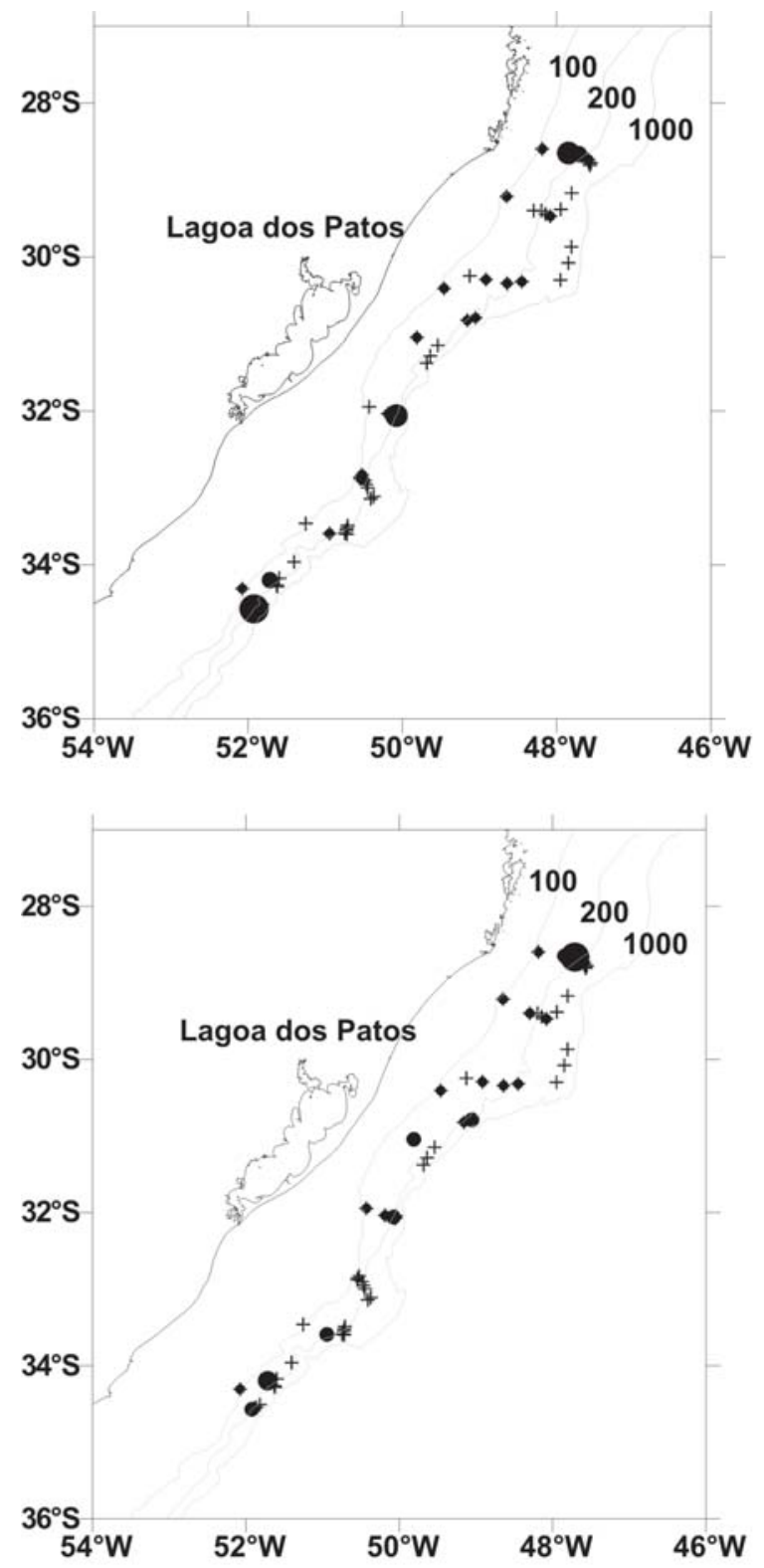

Depth strata of 100-149 and 150-199 m presented higher frequency of occurrence for both sexes during winter. During summer, depth strata of 200-249 and 250-299 presented higher frequencies of occurrence, mainly for females (Table 1). Sex ratio per depth strata was also not significantly different of $1: 1$ in both seasons.

Relation between CPUE, temperature and salinity. It was found a significant variation of temperature relative to depth in all studied area (ANOVA; $\mathrm{F}_{(8,95)}=52.06 ; P<0.001$ ) as well as in salinity of the bottom (ANOVA; $\mathrm{F}_{(8,95)}=50.62 ; P<0.001$ ). There was no significant difference between seasons regarding temperature (ANOVA; $\mathrm{F}_{(1,95)}=0.00 ; P=0.96$ ) or bottom salinity (ANOVA; $\mathrm{F}_{(1,95)}=0.00 ; P=0.95$ ) for all depth
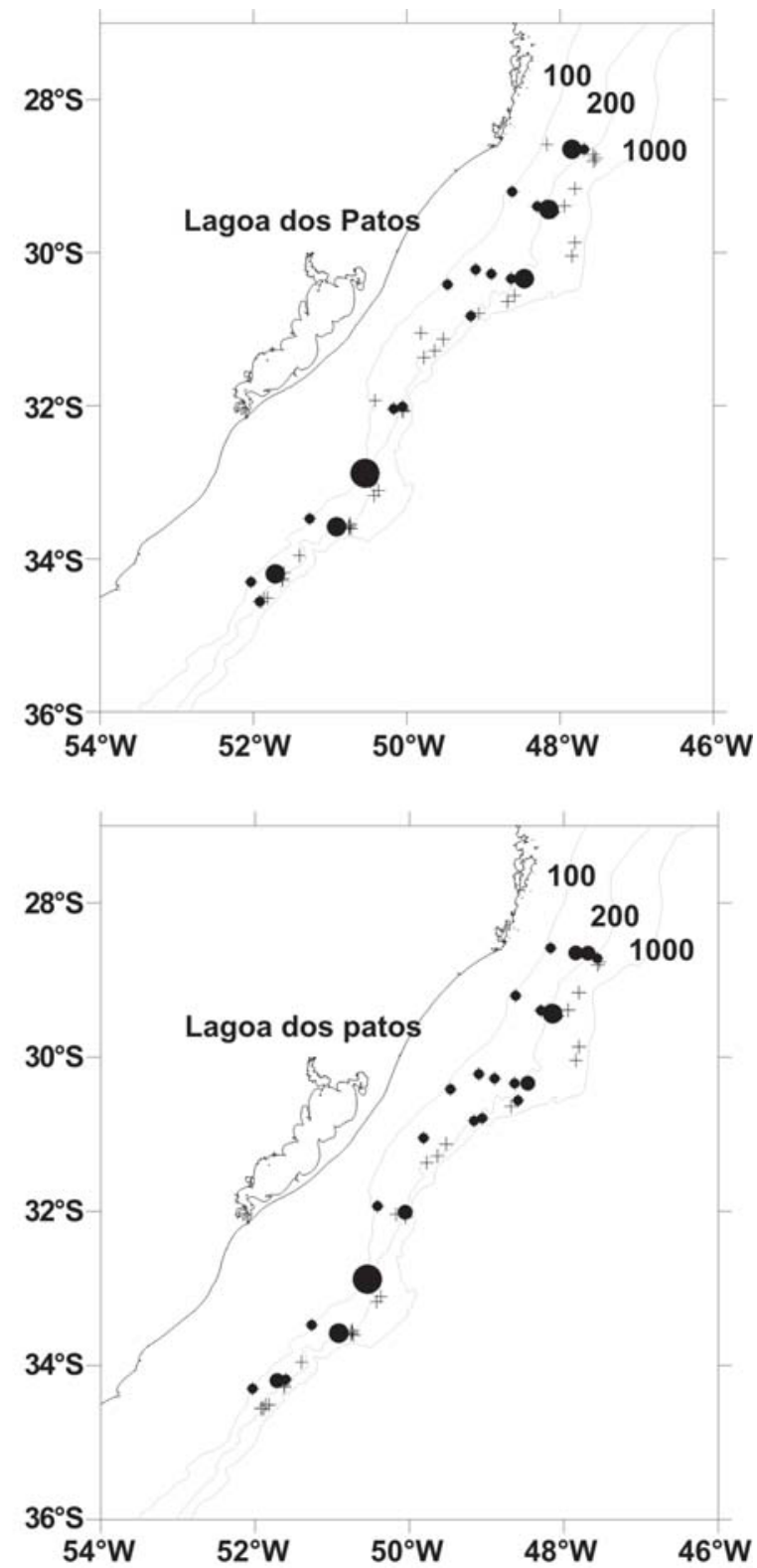

Fig. 1. Maps with the distribution of Atlantoraja cyclophora in southern Brazil according to sex ( $\mathrm{males}=\mathrm{a}$ and $\mathrm{c}$; females $=$ b and d) and season. Black circles represent CPUE as kg/h; 40 to $50 \mathrm{~kg} / \mathrm{h} ; \bullet 30$ to 39,9 kg/h; 20 e $29,9 \mathrm{~kg} / \mathrm{h} ; \bullet 10$ to $19.9 \mathrm{~kg} / \mathrm{h}$; $\bullet 1$ to $9.9 \mathrm{~kg} / \mathrm{h}$. Crosses represent sampling stations of each survey. 
strata (Table 1). Bottom temperature ranged from 5.6 to 16.5 ${ }^{\circ} \mathrm{C}$ in winter and 5.0 to $17.6{ }^{\circ} \mathrm{C}$ in summer. Bottom salinity ranged from 34.2 and $36 \mathrm{ppm}$ in winter and from 34.3 to 35.9 ppm in summer. In the area of occurrence of the species, from 100 to $299 \mathrm{~m}$, temperature ranged between 10.2 and $16.5^{\circ} \mathrm{C}$ in winter and 10.0 and $17.6^{\circ} \mathrm{C}$ in summer, and salinity between 35.2 and $36 \mathrm{ppm}$ in winter and between 35.4 and $35.9 \mathrm{ppm}$ in summer. Mean temperature and salinity were significantly higher in the area of occurrence of the species than in the rest of the area of study (temperature: $\mathrm{t}=14.9$; D.F. $=111 ; P<$ 0.001 ; salinity: $\mathrm{t}=14.4$; D.F. $=111 ; P<0.001)$. In the area of occurrence, the distribution of $A$. cyclophora was not correlated with any of the studied environmental variables, either in a logarithmic or metric scale.

Distribution of the frequencies of total length. In winter (Fig. 2) 115 females ranging from 23.5 to $64.5 \mathrm{~cm}$ TL (mean $=53.0 \pm$ $7.24 \mathrm{~cm}$; mode $=56.0 \mathrm{~cm}$ ) and 103 males ranging from 32.8 to $63.5 \mathrm{~cm}$ TL $($ mean $=51.7 \pm 4.41 \mathrm{~cm} ;$ mode $=54.0 \mathrm{~cm})$ were collected. In summer (Fig. 3), 130 females from 30.8 to $64.0 \mathrm{~cm}$ $\mathrm{TL}($ mean $=52.8 \pm 7.58 \mathrm{~cm} ;$ mode $=60.5 \mathrm{~cm})$ and 111 males with 28.7 to $61.8 \mathrm{~cm} \mathrm{TL}($ mean $=50.1 \pm 6.29 \mathrm{~cm}$; mode $=51.5 \mathrm{~cm})$ were collected.

The grouped distributions of frequencies were asymmetric in summer and in winter. The asymmetry value in summer was -0.93 for females and $-1,10$ for males; in the winter it was $-1,41$ for females and -1.01 for males. This indicates that in both males and females occurred individuals with high values of TL. The asymmetric pattern was also observed when considering the frequencies distribution by depth stratum, with the exception of the 100-149 m stratum for males in winter, the 200-249 m stratum for females in winter, and 250-299 m stratum for females in winter and males in summer. Asymmetry values ranged from 0.14 in females in the $250-299 \mathrm{~m}$ stratum in winter to 2.29 in males in the $200-249 \mathrm{~m}$ stratum in summer; and from -0.40 in females in the $200-249 \mathrm{~m}$ stratum in summer and -2.39 in males in the $200-249 \mathrm{~m}$ stratum in winter.

The distribution of the frequencies of TL by depth is presented in Table 1. The trifactorial ANOVA did not detect significant differences in the interaction between sex, depth and season, but a statistically significant difference was found between TL for sex and depth $\left(\mathrm{F}_{(1,449)}=13.22 ; P<\right.$ 0.001 and $\mathrm{F}_{(3,449)}=5.88, P<0.001$ respectively). These factors were analyzed independently, resulting that the females were significantly larger than males $\left(\mathrm{F}_{(1,449)}=12.62 ; P<0.001\right)$ $($ mean TL for females $=53.2 \mathrm{~cm}$; mean TL for males $=50.9$ $\mathrm{cm})$. It was verified that TL was significantly larger in depths of up to $150 \mathrm{~m}\left(\mathrm{~F}_{(1,449)}=6.67 ; P<0.001\right)$. Mean TL did not vary significantly between the two seasons $\left(\mathrm{F}_{(1,449)}=3.41 ; P\right.$ $=0.07)$. During the analysis, outliers were detected and excluded, without statistic criteria; only by visual inspection of the student residuals with values larger than $|3|$ (Wilkinson 1990).

Morphometry of Atlantoraja cyclophora. There was significant difference $\left(\mathrm{F}_{(2,432)}=27 ; P<0.001\right)$ between sexes in the relations TW-TL and EW-TL $\left(\mathrm{F}_{(2,423)}=8 ; P<0.001\right)$. In both cases, the females were heavier than males (Figs. 4-5), being this more evident in the relation TW-TL. Relations between TL and TW, and TL and EW did not vary significantly with regard to the season. The relation DW-TL also varied significantly between sexes $\left(\mathrm{F}_{(2,431)}=87.4 ; P<0.001\right)$ with females wider than males in individuals with TL larger de $35.0 \mathrm{~cm}$ (Fig. 6). Equations describing these relations are given in Table 2.

Table 1. Temperature $\left({ }^{\circ} \mathrm{C}\right)$ and salinity $(\mathrm{ppm})$ at the bottom; CPUE (kg/h); frequency of occurrence (FO); sex ratio (F:M); and total length - CT (cm) for males (m) and females (f) of Atlantoraja cyclophora according to depth stratum in the winter and summer surveys. Values for temperature, salinity and CT are represented by the mean followed by the minimum and maximum values (in parenthesis).

\begin{tabular}{|c|c|c|c|c|c|c|c|c|c|c|c|}
\hline Depth & Temperature & Salinity & $\mathrm{N}^{\circ} \mathrm{m}$ & $\mathrm{N}^{\circ} \mathrm{f}$ & $\begin{array}{c}\text { CPUE m } \\
(\mathrm{kg} / \mathrm{h})\end{array}$ & $\begin{array}{c}\text { CPUE f } \\
(\mathrm{kg} / \mathrm{h})\end{array}$ & $\begin{array}{c}\mathrm{FO} \\
\mathrm{m}\end{array}$ & $\begin{array}{c}\mathrm{FO} \\
\mathrm{f}\end{array}$ & $\mathrm{F}: \mathrm{M}$ & CT m & CT f \\
\hline \multicolumn{12}{|l|}{ Winter } \\
\hline $100-149$ & $15.6(12.3-16.5)$ & $35.7(32.3-36)$ & 39 & 48 & 4.46 & 6.47 & 71 & 78 & $1.2: 1$ & $52(45-62)$ & $53(23.5-63)$ \\
\hline $150-199$ & $14.8(13.2-16.3)$ & $35.5(35.2-35.8)$ & 37 & 41 & 7.35 & 9.31 & 88 & 63 & $1.1: 1$ & $51.4(32.8-60.6)$ & $53.7(27.6-64.5)$ \\
\hline $200-249$ & $13.7(10.2-16.0)$ & $35.2(34.8-35.8)$ & 17 & 15 & 4.62 & 3.46 & 50 & 50 & $0.88: 1$ & $52(37.7-55.5)$ & $51.8(36.2-59.5)$ \\
\hline $250-299$ & $12.1(11.0-13.2)$ & $35.0(35.0-35.1)$ & 4 & 11 & 1.40 & 5.21 & 50 & 50 & $2.75: 1$ & $46.2(42.5-48.6)$ & $52.9(46.5-61.2)$ \\
\hline $300-349$ & $10.5(6.0-14.0)$ & $34.8(34.2-35.2)$ & 0 & 0 & 0 & 0 & 0 & 0 & - & - & - \\
\hline $350-399$ & $9.6(9.2-10.0)$ & $34.8(34.7-34.9)$ & 0 & 0 & 0 & 0 & 0 & 0 & - & - & - \\
\hline $400-449$ & $8.7(10.0-11.7)$ & $34.6(34.2-35)$ & 0 & 0 & 0 & 0 & 0 & 0 & - & - & - \\
\hline $450-499$ & $8.4(7.6-9.3)$ & $34.6(34.3-34.9)$ & 0 & 0 & 0 & 0 & 0 & 0 & - & - & - \\
\hline $500-549$ & $7.2(5.6-9.2)$ & $34.4(34.3-34.6)$ & 0 & 0 & 0 & 0 & 0 & 0 & - & - & - \\
\hline \multicolumn{12}{|l|}{ Summer } \\
\hline $100-149$ & $15.6(11.6-17.6)$ & $35.6(35.6-35.9)$ & 57 & 58 & 5.89 & 8.74 & 78 & 100 & $1: 1$ & $50.8(32-59.3)$ & $54.4(30.8-65)$ \\
\hline $150-199$ & $14.2(10.0-17.3)$ & $35.5(35.4-35.8)$ & 19 & 17 & 4.74 & 5.07 & 86 & 67 & $1: 1$ & $55.5(31.5-64)$ & $53.5(28.7-61.8)$ \\
\hline $200-249$ & $14.1(13.3-15.3)$ & $35.3(35.2-35.5)$ & 33 & 34 & 5.18 & 9.00 & 57 & 86 & $1: 1$ & $47.4(34-55.2)$ & $50.4(35-62.8)$ \\
\hline $250-299$ & $12.9(11.3-14.5)$ & $35.2(34.9-35.5)$ & 4 & 10 & 1.89 & 5.16 & 33 & 67 & $2.5: 1$ & $50.5(49.2-52.5)$ & $50(36.6-56.7)$ \\
\hline $300-349$ & $11.8(11.2-14.9)$ & $35.0(34.6-35.4)$ & 0 & 1 & 0 & 0.31 & 0 & 0 & - & 51 & - \\
\hline $350-399$ & $10.4(10.2-10.7)$ & 34.8 & 0 & 0 & 0 & 0 & 0 & 0 & - & - & - \\
\hline $400-449$ & $7.3(6.3-8.2)$ & $34.5(34.4-34.7)$ & 0 & 0 & 0 & 0 & 0 & 0 & - & - & - \\
\hline $450-499$ & $6.7(6.0-7.7)$ & $34.4(34.3-34.5)$ & 0 & 0 & 0 & 0 & 0 & 0 & - & - & - \\
\hline $500-549$ & $7.0(5.0-10.3)$ & $34.4(34.2-34.8)$ & 0 & 0 & 0 & 0 & 0 & 0 & - & - & - \\
\hline
\end{tabular}


Table 2. Relation between CT and PT, PE and LD for males (m) and females (f) with the respective equations, correlation coefficients (R) and sample size (N) in Atlantoraja cyclophora.

\begin{tabular}{lcccc}
\hline & sex & Equation & R & N \\
\hline CT-PT & m & PT $=0.0127 * \mathrm{CT}^{2.7966}$ & 0.95 & 203 \\
CT-PT & $\mathrm{f}$ & $\mathrm{PT}=0.0067 * \mathrm{CT}^{2.9797}$ & 0.97 & 223 \\
CT-PE & $\mathrm{m}$ & $\mathrm{PE}=0.0137 * \mathrm{CT}^{2.7581}$ & 0.95 & 198 \\
CT-PE & $\mathrm{f}$ & $\mathrm{PE}=0.01409 * \mathrm{CT}^{2.7609}$ & 0.97 & 226 \\
CT-LD & $\mathrm{m}$ & $\mathrm{LD}=5.042+0.643 * \mathrm{CT}$ & 0.95 & 208 \\
CT-LD & $\mathrm{f}$ & LD $=2.412+0.722 * \mathrm{CT}$ & 0.97 & 227 \\
\hline
\end{tabular}

\section{Discussion}

Atlantoraja cyclophora occurred from 100 to $300 \mathrm{~m}$ deep, without statistically significant differences in the CPUE among depth strata and sexes. Vooren (1997) had already noted that this species reached this maximum depth in the Rio Grande

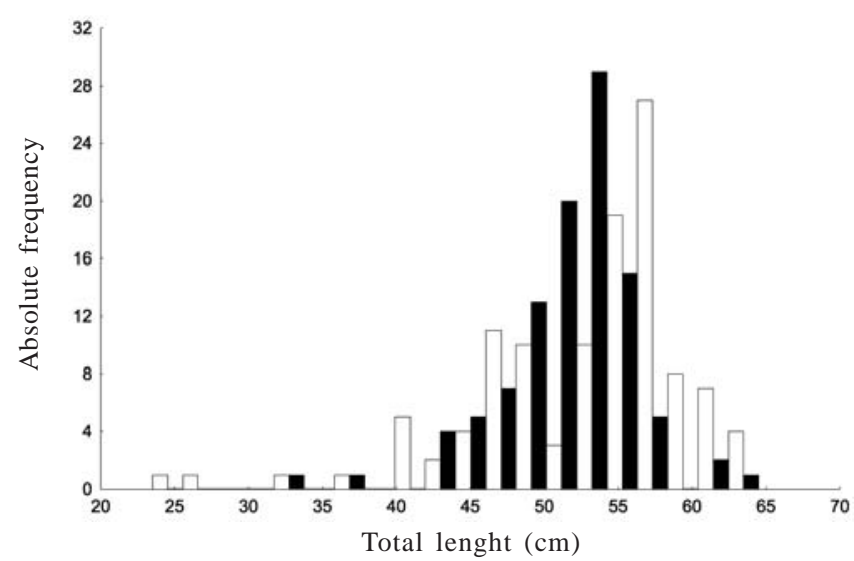

Fig. 2. Frequency of occurrence of males (black columns, $\mathrm{n}=103$ ) and females (white columns, $\mathrm{n}=115$ ) of Atlantoraja cyclophora by total length size classes of $1 \mathrm{~cm}$ in the winter surveys.

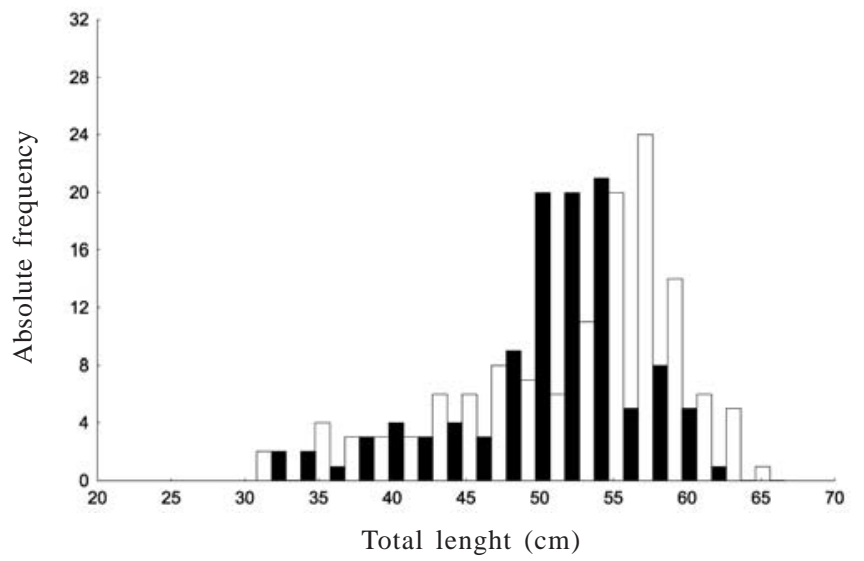

Fig. 3. Frequency of occurrence of males (black columns, $\mathrm{n}=$ 130) and females (white column, $\mathrm{n}=111$ ) of Atlantoraja cyclophora by total length size classes of $1 \mathrm{~cm}$ in the summer surveys. do Sul coast, and registered the minimum depth as the isobath of $50 \mathrm{~m}$. In southern Brazil, Casarini (1999) registered this species from the coast to $100 \mathrm{~m}$ depth, and Ponz Louro (1995) registered in the São Paulo littoral from 10 to 100 m deep, but both papers presented no data collected in depths greater than $100 \mathrm{~m}$. Therefore, the species is herein considered as occurring in most of the continental shelf of southern and southeastern Brazil. In the Rio Grande do Sul coast, the external limit of the species distribution reaches $300 \mathrm{~m}$ deep, but this limit remains unknown for the southeastern Brazil.

Atlantoraja cyclophora distribution was not correlated with depth, temperature or salinity. Temperature was the main factor determining the distribution of Raja clavata (Jardas, 1973). Distribution of the Rajidae in the Argentine sea was also related to temperature, as observed for A. cyclophora, as well as species of the genera Bathyraja, Rioraja, Dipturus, and Psammobatis by Menni \& López (1984). For Sympterygia bonapartii, temperature was the second factor in importance determining species distribution (Mabragaña et al., 2002).

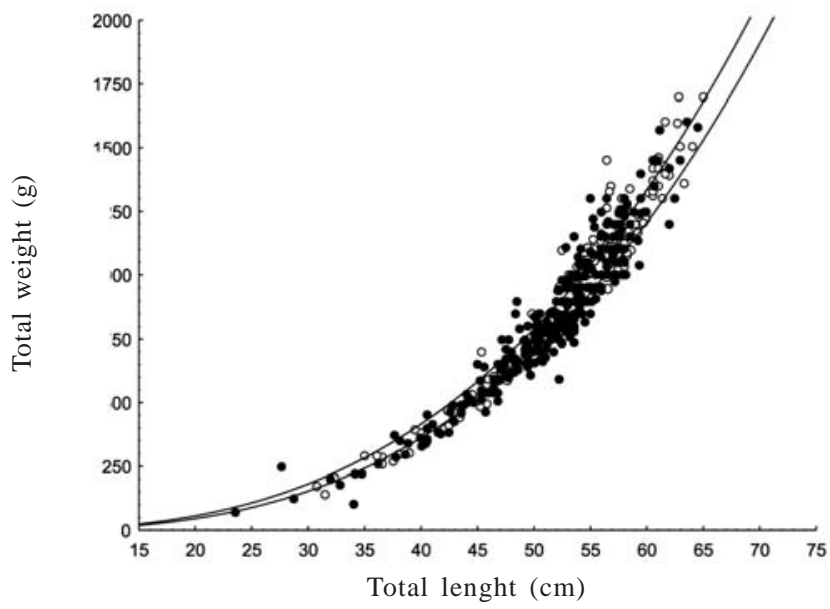

Fig. 4. Relation between total body weight (g) and total length $(\mathrm{cm})$ in males $(\mathrm{n}=203)$ and females $(\mathrm{n}=223)$ of Atlantoraja cyclophora.

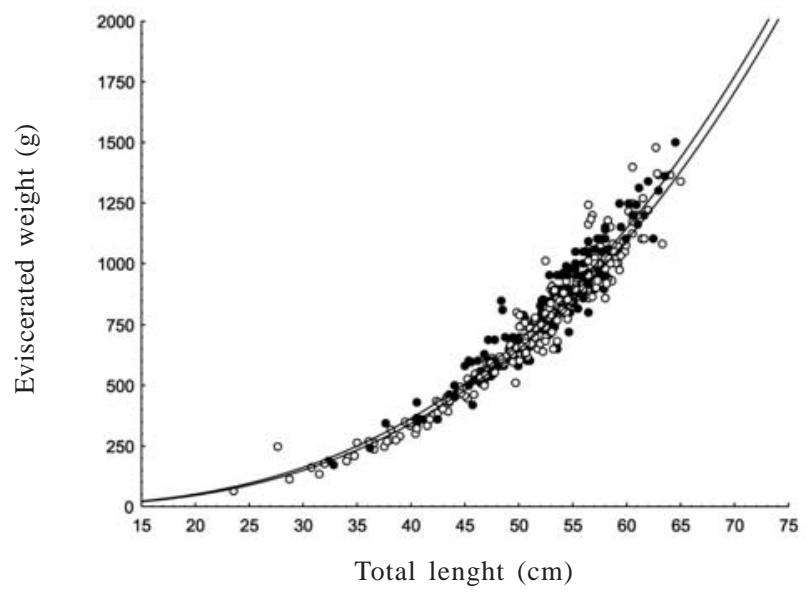

Fig. 5. Relation between eviscerated body weight (g) and total length $(\mathrm{cm})$ in males $(\mathrm{n}=198)$ and females $(\mathrm{n}=226)$ of Atlantoraja cyclophora. 


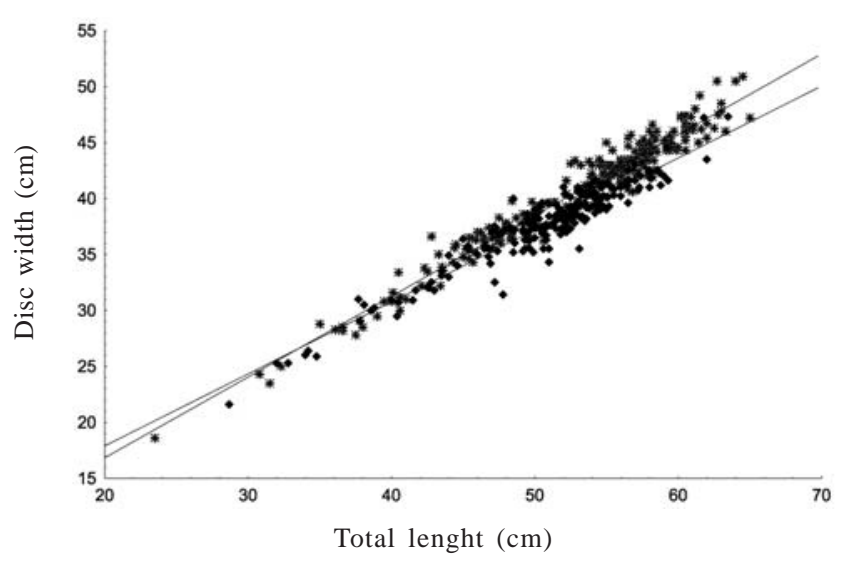

Fig. 6. Relation between disk width $(\mathrm{cm})$ and total length $(\mathrm{cm})$ in males $(n=208)$ and females $(n=227)$ of Atlantoraja cyclophora.

In depths from 100 to $300 \mathrm{~m}$ temperature presented little seasonal variation $\left(12.1^{\circ} \mathrm{C}\right.$ to $\left.15.6^{\circ} \mathrm{C}\right)$. The species was absent between 300 and $600 \mathrm{~m}$ where temperature ranged from 7.2 to $10.5^{\circ} \mathrm{C}$. In the internal limit of distribution of A. cyclophora in the coast of Rio Grande do Sul, in depths of about $50 \mathrm{~m}$, mean bottom temperature is about $20.0{ }^{\circ} \mathrm{C}$ in summer (April) and ranges between 12.0 and $18.0^{\circ} \mathrm{C}$ in winter (August) (Haimovici et al., 1995). Temperature limits of this species in the coast of Rio Grande do Sul are between $12.0^{\circ} \mathrm{C}$ and $20.0^{\circ} \mathrm{C}$.

Temperature and depth ranges preferred by A. cyclophora are included in the ranges found for other species of Rajidae. McEachran \& Musick (1975) listed seven species of Raja from the Atlantic coast of the United States and Canada occurring in depths from 31 to $974 \mathrm{~m}$, but with most species found in depths from 110 to $366 \mathrm{~m}$, with temperature ranging from 2.0 to $20.0^{\circ} \mathrm{C}$. Greater densities of Leucoraja garmani are found in temperatures ranging from 10.0 to $14.0^{\circ} \mathrm{C}$ (Packer et al., 2003). Distribution of A. cyclophora is included in the patterns described for Rajidae: temperate and cold waters of the continental shelf and upper continental slope. The southern Brazil continental margin is influenced by the Subtropical Convergence (CST), formed by the Brazil Current (CB) that flows to the South carrying tropical waters (AT) and the coastal branch of the Malvinas current that flows to the North carrying subantarctic water (ASA). The Brazil/ Malvinas current confluence and mixture of AT and ASA form the Subtropical Water (AST; Temperature $10.0-20.0^{\circ} \mathrm{C}$; S 35-36 ppm) or Central Water of South Atlantic (ACAS) that flows to the North in deep strata in an anticyclonic eddy that may reach the continental margin (Garcia, 1998). Considering the oceanographic characteristics of the area of occurrence of A. cyclophora, we may conclude that it inhabits the ACAS.

In the inner continental shelf and in the border of the continental slope of Rio Grande do Sul, between 50 and $300 \mathrm{~m}$ deep, predominate fine silt and clay sediment, with sandy areas in the north and south extremes of the studied area (Calliari, 1998). This species was found over all this area, without preference by any peculiar granulometry of the sediment, a fact already noted by Casarini (1999) in southeastern Brazil for A. cyclophora. Some species like Raja miraletus, however, have their spatial distribution determined by the sediment (Jardas, 1973).

Egg-bearing females occurred in all depths between 100 and $300 \mathrm{~m}$ (Oddone, 2003), indicating that oviposition occurs in all this depth range. It is expected that juveniles also occur in the same depth range. According to the size of the eggcapsules, the expected TL of the neonate A. cyclophora is about $10 \mathrm{~cm}$. The smallest captured individual, however, measured $23.5 \mathrm{~cm}$ TL, and individuals smaller than $35.0 \mathrm{~cm}$ TL were scarce in the catches. Ponz Louro (1995) observed that egg-bearing females of this species move to depths greater than $50 \mathrm{~m}$ during winter. When samples were pooled, only $18 \%$ of males and $37 \%$ of females were classified as juveniles. The lack of neonates and shortage of juveniles were attributed to the smaller susceptibility of these size classes to be captured by the bottom-trawl net used herein. Specimens of Rajidae are usually partially buried in the sediment when inactive (Bigelow $\&$ Schroeder, 1953). If juveniles are immobile and buried when the bottom-trawl net is passing by they will be probably not captured. The neonates may also escape through the anterior portion of the net, with mesh size of $160 \mathrm{~mm}$ between knots. Neonates and small juveniles were probably abundant between 100 and $300 \mathrm{~m}$ depth, but were not caught due to the ineffectiveness of the sampling method, in such a way that samples partially represented the population. Ponz Louro (1995) and Braccini \& Chiaramonte (2002) verified the absence or rareness of neonates and small juveniles in samples obtained with bottom-trawl net, possibly a general characteristic of all Rajidae. Fishing with bottom trawl net has possibly a low direct impact over juveniles of the species of Rajidae, except by an eventual egg or buried juvenile crushing.

Juveniles and adult of both sexes occurred in all depths between 100 and $300 \mathrm{~m}$. Females predominated numerically only in the 250 and $299 \mathrm{~m}$ strata, but even in these depths occurred males of all sizes. In A. cyclophora, males and females in all development stages have the same spatial distribution and share the same habitat along the year. Such a distribution pattern was also observed for Raja clavata, $R$. erinacea, $R$. miraletus and Psammobatis extenta (Nottage \& Perkins, 1983; Richards et al., 1963; Capapé \& Quignard, 1974; Braccini \& Chiaramonte, 2002) and seems to be a common pattern for Rajidae.

Females of A. cyclophora were significantly heavier than males, fact already noted for other Rajidae, like Psammobatis extenta (Braccini \& Chiaramonte, 2002) and Sympterygia bonapartii (Mabragaña et al., 2002). This difference could be related to the sexually dimorphic liver weight. However, when eviscerated weight was considered instead of total weight, the difference was still observed, although less significant. This may be related to the sexual dimorphism detected in body morphology. Males have a conspicuous concavity in the anterior border between the snout and pectoral fin tip, that is not found in females. Such a sexual 
dimorphism extreme in the subgenus Dipturus (Leible \& Stehmann, 1987), and has been also observed in Raja radula (Capapé, 1974). Differences in the linear regressions between TL and DW between sexes were also noted for Raja clavata by Nottage \& Perkins (1983). Females of A. cyclophora were, for a given TL, wider than males, as already observed by Jardas (1973) in Raja miraletus. The relation between TL and TW, described by a power function, with slope close to 3 , demonstrates that the body proportions are approximately constant (isometric) along body growth. Such a pattern has been also observed in other Rajidae, e.g. Raja radiata (Skjæraasen \& Bergstad, 2000) and Psammobatis extenta (Braccini \& Chiaramonte, 2002).

\section{Acknowledgements}

We acknowledge Roberto Menni, Marlise A. Bembenuti, P. G. Kinas, Miguel Petrere, and two anonymous reviewers for the critical review of the manuscript. This study was financed by CNPq.

\section{Literature Cited}

Barbosa dos Santos, F. \& U. Gomes Leite. 1998. Morfologia juvenil de quatro espécies do gênero Raja (Linneaus, 1758) das regiões sudeste do Brasil (Chondrichthyes, Batoidei, Rajidae). Biociências, 6(2): 125-146.

Bigelow, H. B \& W. C. Schroeder. 1953. Sawfishes, Guitarfishes, Skates, Rays, Chimaeroids. In: Fishes of the Western North Atlantic. Memoirs of the Sears Fundation of Marine Research 1(2)., New Haven: i-Xv + 588 pp.

Braccini, J. M. \& G. E. Chiaramonte. 2002. Reproductive Biology of Psammobatis extenta. Journal of Fish Biology, 61:272-288.

Calliari, L. J. 1998. Características Geomorfológicas. Margem Continental. Pp.101-104. In: U. Seeliger, C. Odebrecht \& J. P. Castello (Eds). Os Ecossistemas Costeiro e Marinho do Extremo Sul do Brasil. Rio Grande. Ecoscientia, 341p.

Capapé, C. 1974. Contribution à la biologie des Rajidae des côtes tunisiennes. II. Raja radula, Delaroche, 1809: Répartition géographique et bathymétrique, sexualité, reproduction, fécondité. Archives de Ínstitut Pasteur de Tunis, 51: 211-228.

Capapé, C \& J. P. Quignard. 1974. Contribution à la biologie des Rajidae des côtes tunisiennes. I. Raja miraletus, Linné, 1758: Répartition géographique et bathymétrique, sexualité, reproduction, fécondité. Archives de Ínstitut Pasteur de Tunis, 51: 39-60.

Casarini, L. M. 1999. Distribuição, abundância, morfometria e aspectos da pesca das raias do gênero Raja (Elasmobranchii, Rajidae) da fauna acompanhante da pesca de arrasto na costa sudeste e sul do Brasil. Unpublished M.Sc. Dissertation. Universidade de São Paulo, São Paulo. 68 pp.

Cousseau, M. B. \& R. G. Perrotta. 2000. Peces Marinos de Argentina: Biología, distribución, pesca. INIDEP. Mar del Plata, 167 pp.
Chase, C. I. 1976. Elementary Statistical Procedures. New York. McGraw-Hill Book Company. 277 pp.

Figueiredo, J. L. 1977. Manual de Peixes Marinhos do Sudeste do Brasil. Introdução: cações, raias e quimeras. Museu de Zoologia da Universidade de São Paulo. 104pp.

Garcia, C. A. E. 1998. Oceanografia Física. Pp. 104-106. In: U. Seeliger, C. Odebrecht \& J. P. Castello (Eds).Os Ecossistemas Costeiro e Marinho do Extremo Sul do Brasil. Seeliger. Rio Grande: Ecoscientia. 341pp.

Haimovici, M., A. Silva Martins \& P. Castelli Vieira. 1995. Distribuição e abundância de peixes teleósteos demersais sobre a plataforma continental do Sul do Brasil. Revista Brasileira de Biologia, 56(1): 27-50.

Hair, J. F. 1990. Multivariate data Analysis with Readings. Macmillan Publishing Company, New York, 449 pp.

Jardas, I. 1973. A contribution to our knowledge of the biology and ecology of thornkack ray (Raja clavata L.) and brown ray (Raja miraletus L.) in the Adriatic. Acta Adriatica, 15(3), 1-42.

Leible, M. D. \& M. F. W. Stehmann. 1987. First Records of Raja (Dipturus) trachyderma Krefft \& Stehmann 1975 from the Southeastern Pacific off Chile, with first descriptions of its clasper characters and additional skeletal and morphological details (Pisces, Rajiformes, Rajidae). Studies on Neotropical Fauna and Environment, 22(4):169-188.

Mabragaña, E., L. O. Lucifora \& A. M. Massa. 2002. The reproductive biology and abundance of Sympterygia bonapartii endemic to the south-west Atlantic. Journal of Fish Biology 60:951-967.

McEachran, J. D. \& J. A. Musick. 1975. Distribution and relative abundance of seven species of skates (Pisces: Rajidae) which occur between Nova Scotia and Cape Hatteras. Fishery Bulletin: 73(1):110-136.

McEachran, J. D. \& K. A. Dunn, 1998. Phylogenetic analysis of skates, a morphologically conservative clade of elasmobranchs (Chondrichthyes, Rajidae). Copeia, 1998(2):271-290.

Menni, R. C. 1972. "Raja" ("Atlantoraja") subgen. nov. y lista critica de los "Rajidae" argentinos (Chondrichthyes, Rajiformes). Revista del museo de La Plata. Sección Zoología, 11: 165-173.

Menni, R. C. \& H. L. López. 1984. Distributional Patterns of Argentine Marine Fishes. Physis, Sección. A, 42 (103): 71-85.

Menni, R. C. \& M. F. W. Stehmann. 2000. Distribution, environment and biology of batoid fishes off Argentina, Uruguay and Brazil. A review. Revista del museo Argentino de Ciencias Naturales, 2(1):69-109.

Nottage, A. S. \& E. J. Perkins. 1983. Growth and maturation of rocker, Raja clavata L. in the Solway Firth. Journal of Fish Biology (23):43-48.

Oddone, M. C. 2003. Biologia Reprodutiva de Atlantoraja cyclophora no Sul do Brasil. Unpublished M.Sc. Dissertation, Fundação Universidade Federal do Rio Grande, Rio Grande. 99 pp.

Packer, D. B., C. A. Zetlin \& J. J. Vitalino. 2003. Rosette Skate, Leucoraja garmani virginica, life history and habitat characteristics. NOAA Technical Memorandum NMFSNE-176. 17 pp. 
Ponz Louro, M. 1995. Estratégias e tácticas reprodutivas de elasmobrânquios no ecossistema de Ubatuba, SP, Brasil. Unpublished M.Sc. Dissertation Universidade de São Paulo, São Paulo. 95 pp.

Skjæraasen J. E. \& O. A. Bergstad. 2000. Distribution and feeding ecology of Raja radiata in the northeastern North Sea and Skagerrak (Norwegian Deep). ICES Journal of Marine Science. 57: 249-260.

Sokal, R. R. \& F. J. Rohlf. 1987. Introduction to Biostatistics. Second Edition. New York. W.H. Freeman and Company. $363 \mathrm{pp}$.

Souza, G. S. 1998. Introdução aos Modelos de Regressão Linear e Não-Linear. Brasília: Embrapa- SPI / Embrapa SEA. 505pp.

Stehmann, M. F. W. 1970. Vergleichend morphologische and anatomische Untersuchungen zur Neuordnung der Systematik der nordostatlantischen Rajidae (Chondrichthyes, Batoidei). Archiv für Fischerei-und Meeresforschung, 21:73-164.
Vooren, C. M. 1997. Demersal Elsamobranchs. Pp. 141-146. In: U. Seeliger, C. Odebrecht \& J. P. Castello (Eds). Environment and Biota of the Patos Lagoon Estuary. Berlim. Springer-Verlag. 308 p.

Uyeno, T., K. Matsuura \& E. Fujii. 1983. Fishes trawled off Suriname and French Guiana. Uyeno, T, K. Matsuura \& E. Fujii (Eds.). Japan Marine Fishery Resource Research Center, Tokyo, Japan. $519 \mathrm{p}$.

Walker, P. A. \& J. Ellis. 1998. In: Biology of Skates. Proceedings of the Biology of Skates Symposium, New Orleans, 1996, Princeton Press.

Wilkinson, L. 1990. SYSTAT: The System for Statistics. Evanston, I. L.: SYSTAT, Inc. 677 pp.

Zar, J.H. 1984. Biostatistical Analysis. Second Edition. Prentice-Hall, Englewood Cliffs, N.J., 718 pp.

Received August 2003

Accepted June 2004 